\title{
The Anthropocene Concept as a Wake-Up Call for Reforming Democracy
}

Jörg Tremmel, Eberhard Karls Universität Tübingen, Institute for Political Science, Melanchthonstraße 36, 72074 Tübingen

Email: joerg.tremmel@uni-tuebingen.de

\begin{abstract}
Human activity has reshaped all parts of the Earth system. For this reason, a vast majority of geologists at the $35^{\text {th }}$ International Geological Congress in Cape Town (September 2016) spoke out in favor of changing the classification of geological epochs and of declaring a new world age - the Anthropocene. This chapter points at implications that the proclamation of the Anthropocene should have for the currently relevant concept of democracy. In particular, it is argued that the transition into a new phase of geology also necessitates a further advancement of our form of government. Democracy, as it has been conceived of and practiced until now, has to a large extent ignored the problem of 'presentism'. This chapter suggests an extension of the 300-years-old separation of powers between the legislative, executive and judicial branch. It is argued that in order to make our political system more future-oriented, there is a need for a new (fourth) branch which ensures that the interests of future generations be taken into account within today's decision-making process. Newly-established embodiments of the proposed future branch, such as offices for future generations (OFGs), could have the right to introduce legislation, integrating the competences of this new institution with those of parliament. The chapter concludes with a discussion about the legitimacy of the proposed change of the institutional architecture of democracies.
\end{abstract}

\section{Note:}

An abridged version of this text (without photos) will be published in:

The Anthropocene Debate and Political Science. Edited by T. Hickmann / L. Partzsch / P. Pattberg / S. Weiland. Routledge Environmental Research Series. London: Routledge. Forthcoming Oct 2018. 


\section{Anthropocene and ethics}

\section{Classifying the history of Earth in geochronology}

The need for designating geological eras first came up when the theological doctrine that the Earth had to be at most 6000 years old according to the bible was refuted during the age of the

Enlightenment. ${ }^{1}$ This was a turning point in the human conception of self. The grasping of basic geological facts since the end of the $17^{\text {th }}$ century, most notably the insight into the Earth’s strikingly old age, rank among the most important achievements of human thought. The invention and refinement of a geological time scale to subdivide 4.6 billion years of Earth history has implications for the self-concept of humanity that can hardly be overstated. For only now do humans know where they stand. Against this background, the significance of the pending proclamation of the Anthropocene becomes clear: It, too, may significantly alter the human conception of self. It is thus with good reason that the idea of labelling our current age the 'Anthropocene' has attracted wide interest as of late. A Google scholar-search in February 2018 with the term 'Anthropocene' coughs up around 51,500 results; dozens of eminent readings are listed on the 'Anthropocene' article at wikipedia.org, and first academic journals with 'Anthropocene' in the title have been founded.

Literally speaking, the term 'Anthropocene' can be translated as the 'Epoch of Men' or 'Age of Men', with 'anthropos’ (Ancient Greek: 'human') connected to the suffix '-cene' used to designate new geological epochs. According to the geological timescale currently in place, we have been living in the Holocene for roughly the past 11,700 years. 


\begin{tabular}{|c|c|c|c|}
\hline System & Series/Epoch & Stage/Age & $\begin{array}{c}\text { Age } \\
\text { (million years) }\end{array}$ \\
\hline \multirow{5}{*}{ Quaternary } & \multicolumn{2}{|l|}{ Holocene } & $0,0117(-?)$ \\
\hline & \multirow{4}{*}{ Pleistocene } & $\begin{array}{l}\begin{array}{l}\text { Late Pleistocene } \\
\text { (Tarantian) }\end{array} \\
\end{array}$ & $0,126-0,0117$ \\
\hline & & $\begin{array}{l}\text { Middle Pleistocene } \\
\text { (Ionian) }\end{array}$ & $0,781-0,126$ \\
\hline & & Calabrian & $1,806-0,781$ \\
\hline & & Gelasian & $2,588-1,806$ \\
\hline \multirow{8}{*}{$\begin{array}{c}\text { Neogene } \\
\text { (the newer part of } \\
\text { tertiary) }\end{array}$} & \multirow{2}{*}{ Pliocene } & Piacenzian & $3,6-2,588$ \\
\hline & & Zanclean & 5,333-3,6 \\
\hline & \multirow{6}{*}{ Miocene } & Messinian & $7,246-5,333$ \\
\hline & & Tortonian & $11,62-7,246$ \\
\hline & & Serravallian & $13,82-11,62$ \\
\hline & & Langhian & $15,97-13,82$ \\
\hline & & Burdigalian & $20,44-15,97$ \\
\hline & & Aquitanian & $23,03-20,44$ \\
\hline
\end{tabular}

Table 1: Excerpt of the currently valid geological timescale.

Note: For the full picture, including the major events of each epoch, see https://en.wikipedia.org/wiki/Geologic_time_scale. The 'correct' subdivision of earth history into systems, series and stages in chronostratigraphy or into periods, epochs and ages in geochronology has always been a matter of serious dispute within geology. It took centuries to compare rock formations across the globe and to integrate them into the current framework.

The term 'Anthropocene' was coined most notably by Nobel laureate in Chemistry Paul J. Crutzen, the discoverer of the ozone hole. ${ }^{2}$ In 2002, for instance, he published a brief article in Nature (Crutzen 2002, 23) entitled Geology of Mankind, which inspired a great number of geologists. In the stratigraphic (the science of strata) community, a Subcommission on Quaternary Stratigraphy was instituted in 2008 in order to collect evidence in mainly three 
different areas: lithostratigraphic (novel sediments, minerals, and mineral magnetism), biostratigraphic (macro- and micropaleontologic successions and anthropogenic traces of life), and chemostratigraphic (organic, inorganic, and radiogenic). The task of the commission is to resolve, by scientific means, the question of whether humankind has become a factor which creates geological changes to an extent which in the past was deemed sufficient for declaring the end of an epoch and the beginning of a new one (Waters et al. 2016).

At the $35^{\text {th }}$ International Geological Congress in Cape Town (September 2016), the members of the subcommission voted almost unanimously in favour of changing the classification of geological epochs and of declaring a new world age - the Anthropocene. This, however, does not mean that the official classification of geological epochs is a done deal or that schoolbook publishers should start rewriting their textbooks. ${ }^{3}$ The reason for this is that, within geology, a number of subdisciplines are in charge of geological classification. Chronostratigraphy classifies strata according to their age of origin. Geochronology is more interpretative, and compiles the unfiltered facts into a geological timescale, that is, into a partitioning of Earth history into meaningful stages. Superior committees that are yet to be convinced include the International Commission on Stratigraphy (ICS) and, as a last step, the executive committee of the International Union of Geological Sciences (IUGS). A final vote has not yet been scheduled, but the odds are good that the Anthropocene will formally be proclaimed within the next few years.

\section{Evidence for a shift in the geological epoch}

With regard to the lithostratigraphic evidence, one marker is the urban structures that currently cover around three to five percent of the Earth's land surface. As a result of urbanisation, large areas are by now covered by a mixture of concrete, glass and metals. Even if humankind were to go extinct tomorrow, those structures would remain where they are for millennia to come. If in a few thousand years from now, if geologists were to visit the place where a large city is standing today, they would discover fragments of concrete, rusted iron, the bitumen of roads, glass from fibre optic cables, and an enormous of amount of aluminium which as such is not found in nature.

Another signature of humankind is visible in the non-decomposing layers of plastic garbage currently floating in the maelstrom of certain ocean drifts. There is evidence suggesting that they create sedimentary deposits after subsiding. In mid-2014, geologists discovered 
structures formed by plastics, volcanics, coral fragments and sand grains off the coast of Hawai'i which, in view of their solidness, they labelled as a stone of its own kind - as plastiglomerate (Chen 2014). However, humankind also creates new sedimentary structures by ablating mountains, filling up valleys, and impounding huge seas. Three-quarters of the ice-free mainland are no longer in the state they used to be in when the human species emerged (Leinfelder 2017). The shifting from wilderness to grasslands in particular is an important marker of the enormous changes humanity has brought upon the Earth's surface. While the proportion of non-wilderness was minimal 12,000 years ago, more than a third of the Earth's surface is being used as grassland for livestock even today. If one were to place all mammals on a huge scale, one could figure out that humans and their livestock accounted for 0.1 percent of all biomass at the beginning of the Holocene, while today this share has grown to 90 percent of all biomass (Vince 2011).

Further examples of the unprecedented depth and long-term nature of human interventions include:

1. The harvesting of subterranean forests, that is, the extraction of coal, oil and gas from the lithosphere. If ever, it would take hundreds of millions of years for these resources to regenerate.

2. The anthropogenic contamination by radioactivity, the timescale of which is likewise only measurable in millions of years.

3. The worldwide flora and fauna species extinction caused by the human species. Nature is always in the process of creating new species, so it is indeed only a matter of time until the ramifications of the sixth mass extinction will have been 'processed' by nature. However, this too will run into the low millions of years time-wise.

4. Climate change, by comparison, is reversible within a much shorter time frame, but here too we are dealing with tens of thousands of years.

5. Space debris has been accumulating in the Earth's orbit since the beginning of space travel, and the forces of nature alone will be unable to dispose of it within the next few thousands of years.

When should the beginning of the Anthropocene be set? Points in time that are conceivable but have now been ruled out include the beginning of agriculture as well as the beginning of the industrial revolution. Many researchers argue in favour of the 1950s, since a large number of indicators have been skyrocketing ever since then. Be it urbanisation, ${ }^{4}$ primary energy 
consumption, or international air travel - one can date the beginning of several processes of exponential growth to the time after World War II, which for that reason has also come to be known as the 'Great Acceleration' (Steffen et al. 2016). However, some indicators - such as the global population - have been on the rise for a somewhat longer period of time, while other indicators of the Earth system - such as the depletion of the stratospheric ozone layer have begun to rise only more recently. A preliminary majority decision by the 37-member subcommission declared 16 July 1945 - the day of the first atomic-bomb blast - to be the least-worst solution. The signature of long-lived plutonium from mid- $20^{\text {th }}$ century bomb blasts in the sediments will remain visible for thousands of years. This is an unambiguously scientific marker of human impact on the environment.

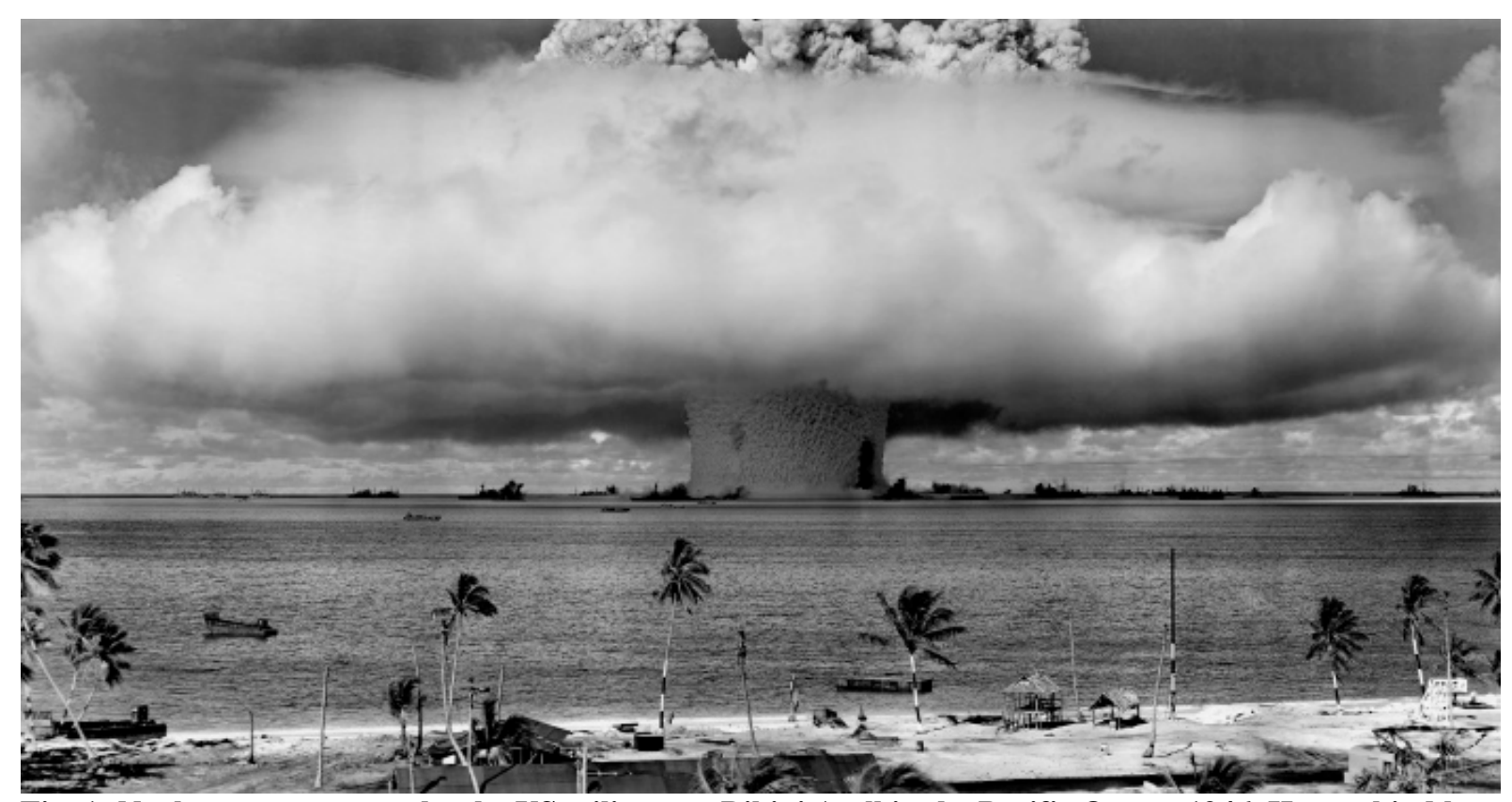

Fig. 1: Nuclear weapons test by the US military at Bikini Atoll in the Pacific Ocean, 1946. Humankind has altered the distribution of radionuclides on our planet abruptly and profoundly.

Source: U.S. Department of Defense

Are there counter-arguments against the proclamation of the Anthropocene? To be sure, the impact of humankind on the length of the Earth's history is miniscule. This can be illustrated by a thought experiment by which the history of the planet Earth is converted into one calendar year. The Earth is around 4.6 billion years old. Recalibrated to fit into one calendar year, one hour equals 525,114 years, one minute is 8,752 years and one second is 145 years. In this scale, no humans appeared on the surface of the Earth between 1 January and 30 December. On the first hours of 31 December, the first human-like apes (hominids) showed up. Bipedal walking was still hours (i.e. millions of years) away. Around 20:30 (8:30 pm), members of the species homo erectus managed to exit from Africa. At 48 minutes before 
midnight, they learned to tame the fire; some minutes later they started cooking, and again some minutes later they started wearing clothes. Anatomically modern humans appeared around 23:36 and they developed a number of sophisticated languages in different places on the Earth. The first sculptures and paintings were created around 23:54. The Neolithic Revolution (the start of agriculture) took place around 81 seconds before midnight. At 23:59:24 the first big cities in Egypt and the Indus Valley were built; nevertheless, the alphabet and the wheel had still not yet been invented. By 18 seconds before midnight on 31 December, the first states and empires had been established (Classical Greece, Roman Republic, Qin Dynasty, Ashoka Empire), and humankind started to record history. The takeaway of this story: the Great Acceleration in the 1950s happened less than one second before midnight on this time scale!

As the history of the Earth until now is subdivided more or less equally in ages, as indicated by Table 1, each of them usually designates a period of several million years. The Pliocene encompasses 2.745 million years, the Pleistocene 2.5763 million years, the Holocene just 0.0117 million years so far. A counterargument to the proclamation of a new age might be that, until much more time has passed, there is simply no vacancy for a new age according to the established nomenclature. But this seems to be an artificial argument. Apart from tradition, there is no problem with 'smaller-amount-of-time' ages. If the real-world phenomena change at a quicker pace than before, the nomenclature employed by geologists can legitimately be adjusted to keep pace with this.

In the debate about the Anthropocene, it is important to separate empirical from evaluative questions. The questions discussed above (If we humans were to perish, would the impact of our existence continue to remain for a long time? Or would everything return immediately to the way it was before our formation?) are, first of all, empirical questions. But these questions also have an evaluative dimension. The notion of the Anthropocene forces us to redefine our place in the world, since it addresses humankind in an entirely new way.

\section{Holocene ethics and Anthropocene ethics}

The thoughts of the Ancients, particularly in matters of ethics, were considered to be timeless and ever-new for more than two thousand years. That this holds true even today, at least in parts, is expressed by the witticism that "where questions of the right life are concerned, only that which is false can be truly new” (Spaemann 1989, 9, own translation). This notion, 
however, is currently brought into question by the concept of the Anthropocene. The ethics developed in Ancient Greece was concerned with the vicinity, with dealing with neighbours, other estates, the other sex. One might call it an 'ethics of neighbourhood' (Tremmel 2009, p. $3)$.

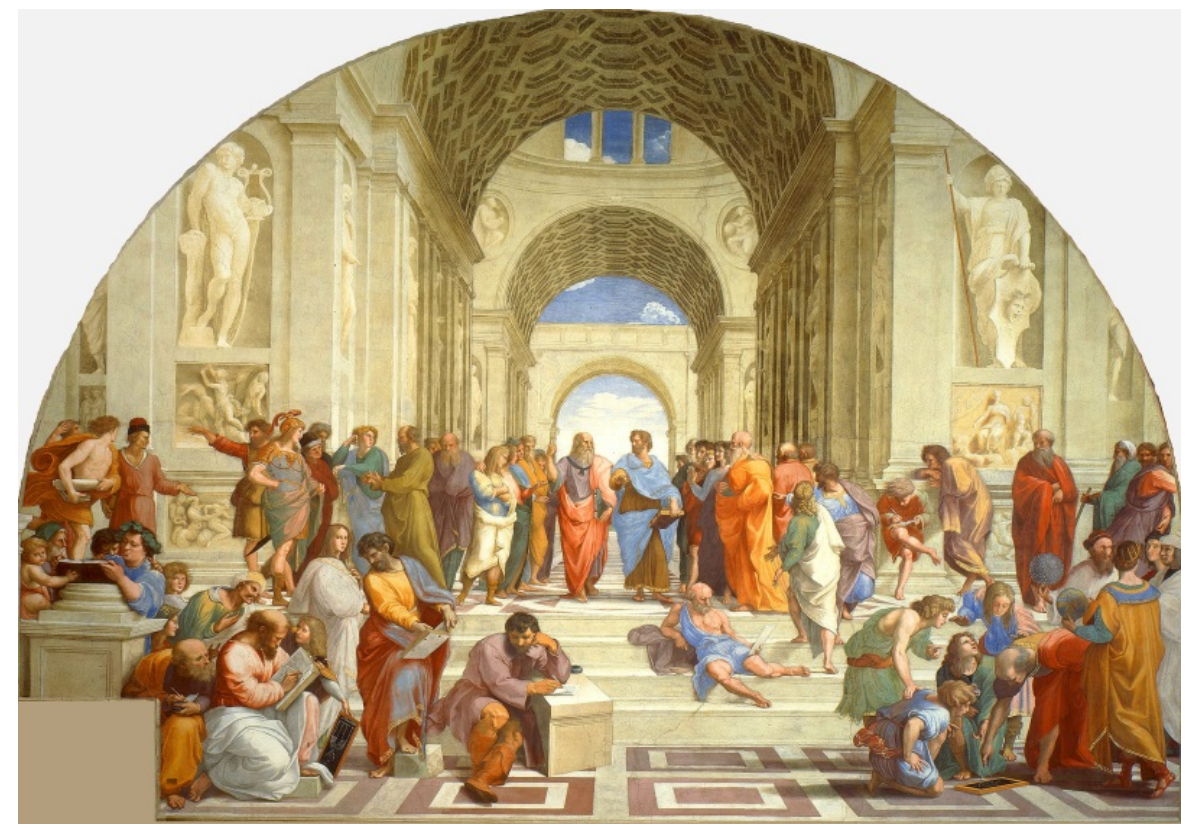

Fig. 2: The School of Athens. The fresco by Raphael, completed in 1511, is world-famous. It expresses the veneration accorded to ancient Greek thinkers during the age of the Renaissance.

Source: Wikimedia Commons

In this ethical realm, humans living on the other side of the world were as little an object of ethical considerations as humans living 500 years in the future. To put it pointedly: Plato did not know of plutonium. In his epoch-making book The Imperative of Responsibility: In Search of Ethics for the Technological Age, the philosopher Hans Jonas carved out what was once true, or, as one might say, what used to be true during the Holocene:

"that, for all his boundless resourcefulness, man is still small by the measure of the elements: precisely this makes his sallies into them so daring and allows those elements to tolerate his forwardness. Making free with the denizens of land and sea and air, he yet leaves the encompassing nature of those elements unchanged, and their generative powers undiminished. [...] Much as he harries Earth, the greatest of gods, year after year with his plough - she is ageless and unwearied; her enduring patience he must and can trust, and to her cycle he must conform” (Jonas 1984, 3). 
In view of the fact that this was no longer true in the second half of the $20^{\text {th }}$ century, Jonas urged a new ethics which would transcend the spatial and temporal vicinity. The fields of 'global ethics' and 'future ethics' that since have been more and more established as ethical subdisciplines of their own are therefore distinctly new phenomena. ${ }^{5}$ Ethical theories developed before the Anthropocene might increasingly become outdated. At any rate, it should be undisputed that the house of ethics stands in need of at least some new rooms.

\section{Hercules in Olympus or Gulliver in Lilliput?}

One implication of the proclamation of the Anthropocene evolves around the human conception of self. The narcissism of medieval man has suffered two great wounds from scientific progress, as Sigmund Freud famously put it in his General Introduction to Psychoanalysis (Freud 1920, 246) The first wound, known as the 'cosmological blow', was the discovery that the Earth is not, in fact, at the centre of the universe (Copernican Revolution 1543). Humankind thereby lost its central position within the cosmos. Roughly three hundred years later, the so-called 'biological blow' occurred when it was discovered that humankind is embedded in the developmental system of the organisms (Charles Darwin 1859 and others). The species Homo sapiens is a product of evolution just as millions of other species are. In both cases, humankind's belief in its central position within the cosmos or within animated nature was deeply shaken by the findings of modern natural science.

The Anthropocene discourse does not add a further blow. On the contrary, the notion of an 'age of men' has the connotation that humankind, as a collective, is much more powerful than previously thought. Human leverage is much bigger than one used to think in the early days of the environmental movement. However, one must be beware of the naturalistic fallacy. The fact that the human species has become a quasi-geological force at its current point of existence surely does not mean that this state of affairs is imperative. This would be the same naturalistic fallacy as if a political philosopher were to infer from the mere existence of a certain form of rule that this particular form of rule ought to exist.

What is new about the Anthropocene is not the insight that humankind changes nature in various ways - this much was known in the $20^{\text {th }}$ century. Rather, the concept of an Anthropocene implies that the human species affects its environment in a deeply profound and long-term way through unconscious, almost incidental actions. Consider, by way of example, the ozone hole. As is well known, chlorofluorocarbons (CFCs) used to occur mainly 
in deodorants, air conditioners and fridges. It is unsettling that a few inventions designed to raise human comfort just by a little should have such grave effects on the stratospheric ozone layer.

Humankind was equally surprised at its degree of impact with regard to the problem of plastic garbage in the oceanic currents. In the 1980s, scientists were still used to assuming that the plastic particles were environmentally irrelevant, since the oceans were thought of as huge and resilient. It was a surprise to our species to find an enormous layer of plastic (some have called it a plastic continent) in the vastness of the Pacific Ocean, and yet more garbage patches in similar out-of-the-way places that are of little interest to humankind and that have hardly ever been visited.

For the self-image of humankind and its view of the environment, there are two possible interpretations of the geological facts. The first is that humankind has become a new Hercules. The other - and, in my view, better - interpretation compares him to the role of Gulliver. Hercules is the great, invincible hero, assertive and often ruthless, someone who is able to perform the most difficult labours with ease. Gulliver, however, has to come to grips with a new environment that only at first sight resembles his familiar environment. In the socio-critical novel by Jonathan Swift published in 1726, the Lilliputians referred to Gulliver as the Man-Mountain. Gulliver himself must quickly learn to move slowly in what is to him the unknown Land of Lilliput. Gulliver knows that there is much he does not know; and he is also aware that, due to his height, every misstep (literally speaking) can have disastrous consequences for his environment. He soon realises that, despite of his size, he himself is in danger, too, precisely because he has troubles adapting to his environment. The story of Gulliver seems perfectly suited to serve as the core narrative of the Anthropocene. This story could represent the idea that the human species increasingly changes its surrounding nature without (yet) being capable of controlling the negative consequences of these changes.

In view of growing insights on the unintended consequences of human actions, fantasies of power and doability - think of climate engineering - should be discouraged rather than promoted. Rather than acting as a new Hercules, who masterfully triumphs in one quest after another, humankind should behave and act as a Gulliver. 


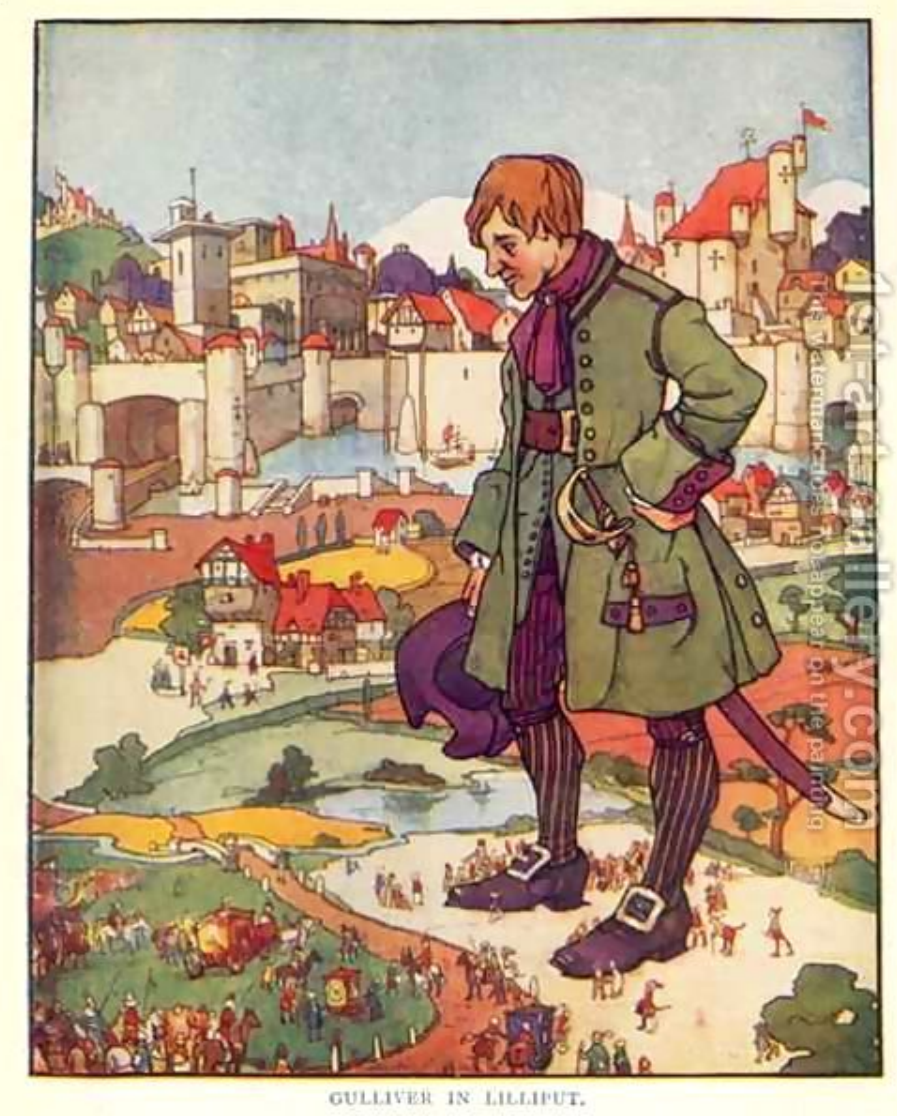

Fig. 3: Gulliver in Lilliput.

Source: www.1st-art-gallery.com/thumbnail/368897/1/Gulliver-In-Lilliput.jpg

\section{Reforming democracy}

A wake-up call that is overdue

The ecological crisis brings the failure of our current way of living to the fore. All political efforts since the beginning of explicit environmental and sustainability policies in the 1970s have fallen short of what is necessary. "The measures taken, important though they might have been for particular regions and sectors, were unable to impede the great acceleration from a global perspective, and have mostly just led to spatial or temporal relocations. A sustainability science which takes the provocation posed by the Anthropocene seriously ought to be dealing with this skandalon” (Görg 2016, 10, own translation).

Almost all key indicators for ecological performance are turning bad. Take, for instance, human-made climate change: The curve of global greenhouse gas emissions continues to point steeply upwards, despite enormous efforts to reduce anthropogenic emissions. The only traceable drops occur during wars and economic crises. In 2009, the global financial and 
economic crisis led to a decrease in global greenhouse gas emissions of 1.3 percent. Already in the following year, however, emissions went back to a growth of 5.9 percent.

One should draw a distinction between indicators which could be seen as more of a direct consequence of government policy and ones whose causes are less directly attributable to government policy, or are more closely related to the power of economics and individual choices. Put differently, there is an important distinction in measuring how certain countries are governed, on the one hand, and how certain societies behave. While it is true that not all indicators are amenable to the levers of government policy, the rest of this chapter argues the case for improving our political institutions. The fact that far too few people maintain an environmentally sustainable lifestyle can (and should) be influenced by policies.

It is not very controversial any more in philosophy that the 'neighbour ethics' that was very useful in the Holocene is of limited use for the future in this new era. But it is less understood that the ecological crisis is also a crisis of democracy as a form of government. Our political institutions, as we know them, were designed in and for the Holocene. The transition into a new phase of geology necessitates a reform of these institutions, namely parliamentarianism. One should not think of 'the Anthropocene concept' as just another frame, but rather understand it as an eye-opener and a wake-up call to reform democracy.

Before outlining what such a reform might look like, two caveats seem to be necessary: one with regard to the superiority of democracy to all other forms of political rule; the second with regard to the limited use of posterity protection clauses in constitutions.

Democracy as a valuable inheritance for future generations

Reforming democracy, to be sure, does not mean calling its essential value into question. Since the 1970s (e.g. Ophuls 1977), some unnecessary ink has been spilt pleading for an ecoauthoritarian ‘solution' (for a summary, see Hammond/Smith 2017). Especially after a series of failed international climate conferences between 2009 and 2014 before the success in Paris 2015 (and then again when US president Donald Trump opted out of this accord in 2017), several contributions to the debate asked whether democracy is the best form of government to cope with ecological challenges (Shearman/Smith 2007, Randers 2012). 
This provocative question is misleading, whether it is answered in the affirmative or not. At any rate, the international climate conferences are a bad case in point, given that not only democratic but also non-democratic nation-states contributed to the failure of the negotiations. Comparative studies have shown that the environmental performance of authoritative regimes is worse than that of democracies (Jänicke 1996). On average, authoritarian regimes display less concern for the future interests of their citizens, and they typically engender patronage and corruption (Boston 2017). So-called epistocrats (proposing rule by those who have knowledge) could reply in return that they don’t advocate authoritarianism per se, but an enlightened non-democratic rule. One lesson from history is that there is no way to ensure that an enlightened dictator does not abandon his benevolence eventually. Some 150 years ago, at a time when intellectuals open-mindedly discussed whether or not democracy is better than monarchy or aristocracy, Mill wrote sensible words that are still (or again) worth reading today:

"In no government will the interests of the people be the object, except where the people are able to dismiss their rulers as soon as the devotion of those rulers to the interests of the people becomes questionable” (Mill 1977, 73).

In the long run, no other form of government but democracy is better suited to solving global environmental problems.

\section{Posterity protection provisions in constitutions do not suffice}

The growing acceptance of responsibility for future generations has led to the trend of including posterity protection clauses in constitutions. Insofar as constitutions have been newly adopted - for example in Eastern Europe and Central Asia after 1989, or in South Africa after the end of apartheid - a regard for generations was inscribed in almost all of these cases. Even well-established constitutions were changed in order to reflect the increasing future-mindedness of citizenries around the world. Five constitutions speak explicitly of 'rights of future generations': Norway (art. 110b), Japan (art. 11), Iran (art. 50), Bolivia (art. 7), and Malawi (art. 13, art. 11). In other constitutional texts, for instance in art. 37 (4) of the Georgian constitution, the 'interests' of future generations are addressed; alternatively their 'needs', e.g. in the constitution of Uganda (Art. XXVII ii). 
The number of constitutions with posterity protection clauses is already considerable, and it continues to grow. But does this make any difference? A sobering conclusion seems in order. The establishment of such clauses has resulted neither in the phasing out of nuclear power nor in serious climate action in the respective countries. Constitutional courts are obviously not optimal to serve as the guardians of future generations' interests: they cannot represent such interests with full commitment for the simple reason that they have no mandate to do so.

\section{Paradigm shift from a three- to a four-power-model}

What is required in the Anthropocene is nothing less than a paradigm shift. The new paradigm would entail a 'future branch', and regard it as a legitimate and necessary part of a democratically constituted community. The linchpin of this paradigm would be that the ageold separation of powers into legislative, executive and judicial branches is no longer sufficient in the Anthropocene. The present-day demos of the $21^{\text {st }}$ century can affect the living conditions of a future demos far more than in former times. Just as in the $18^{\text {th }}$ century, when in the course of first establishing a democracy in a large territorial state, the Federalist Papers considered a system of checks and balances to protect minorities against the 'tyranny of majority' (Tocqueville 1835/1840), so today we are in need of checks and balances against the tyranny of the present over the future.

It seems appropriate to draw on the history of ideas to conceptualise the new 'future branch'. The historical roots of the separation of powers are usually associated with the political theorists John Locke and Charles de Montesquieu. However, even a thinker as early as Aristotle already recommended a mixed constitution or, more specifically, a mixture of democracy and oligarchy, which he called 'politie', designed to prevent an excessive concentration of power. In his Two Treatises of Government, published in 1690, John Locke distinguishes between legislative and executive, but leaves no room for an independent third judicial power. Locke introduces a clear hierarchy of powers when he writes that "this legislative is not only the supreme power of the common-wealth, but sacred and unalterable in the hands where the community has once placed it” (Locke 1823, Chapter XI, § 134).

Montesquieu, the actual father of the tripartite separation of powers doctrine, applies the classical division of legislative, executive and judiciary power in his De l'esprit des lois of 1748. In the sixth chapter of the 11th book (Montesquieu 2001), which mainly deals with the English constitution, he is concerned with the sharing and balancing of powers. Montesquieu 
(2001, 173) writes: "In every government there are three sorts of power: the legislative; the executive, in respect to things dependent on the law of nations; and the executive, in regard to things that depend on the civil law.” Following this statement, Montesquieu explains that this latter power is to be referred to as the judiciary power of the state. This brings us to the classic tripartite division of legislative, executive and judicial power.

The trias politica was conceived by thinkers in the $17^{\text {th }}$ and $18^{\text {th }}$ century and is now universally established in Western democracies. The view of our present three-power-model changes when we learn about the evolution from a two- to a three-power-model in the approaches of Locke and Montesquieu. The most important lesson from the history of ideas seems to be that even the supposedly definitive present is only a stage between the past and the future. The tripartite division was sufficient for the past; but at the brink of the $21^{\text {st }}$ century it does not suffice any more.

A few remarks with regard to the 'vertically' directed separation of powers seem appropriate. In federal states like Germany, for example, the federalisation of political systems means the division of labour between a local level, a Länder level and a national level, complemented by the European Union (EU). The Länder have governments, parliaments and constitutional courts. The European level also has a parliament (the EU parliament), a court (European Court of Justice) and a sort of government (the European Commission). In a four-power system, all such levels should get 'future branches' as well to complement their 'horizontal' separation of powers.

Apart from the horizontal and vertical 'separation of powers', further overloading the term is of little use. The media is also often referred to colloquially as 'the fourth power'. The same applies for interest groups such as trade unions or employers' associations. It is true that the power of the political system does not fully penetrate other autonomous areas such as business, science, media, religion, or private relationships; however, to prevent confusion the term 'separation of powers' should continue to refer to the organisation of state power. The terminology used here counts only the 'branches of government' (not society) and adds a fourth such branch to the existing three.

The legislative branch passes the laws, the executive branch implements them, and the judiciary controls their abidance. Constitutional courts also check the constitutionality of laws 
after the legislative branch has passed them. Where does the 'future branch' fit in here? This branch could be designed as a body which checks the sustainability of laws, and quashes them if they harm future citizens. Alternatively, it is quite possible to see the 'future branch' somewhat closer to the legislative than to the judiciary branch, namely as a body with the right to initiate legislation instead of preventing it.

It should not be forgotten that the idea of the trias politica currently varies from country to country as a result of different traditions of political thought. With regard to institutions for future generations, there cannot be a one-size-fits-all solution; rather, it seems apt to conceive of such a representative body differently for each country. 'Future branch' is thus an umbrella term that does not designate a particular model. Instead, it refers to all institutions for future generations that are powerful enough to credibly represent the needs and interests of future citizens. Throughout the globe, there are now a considerable number of organisations with a mandate for sustainability and intergenerational justice. However, most of these enjoy merely consultative status. They exercise little actual power in a Weberian sense: "Power means every chance in a social relation to realise one's own will even against the resistance of others” (Weber 1922, § 16, own translation).

\section{The legitimacy of a future branch}

\section{Repudiating the charge of 'dictatorship'}

The idea of a fourth branch is new and has not been aired in political science, philosophy or law so far. As a reaction to the ecological crisis, a number of scholars and institutions (e.g. WBGU 2011) have called for a transformation of our society that goes beyond marginalia, but they have not called for a Four-Power-Model. Nevertheless, the discussion about institutions for the representation of future generations is well under way (Stein 1998; Barry 1999; Eckersley 2004; Thompson 2010; Read 2011; González-Ricoy/Gosseries 2016; Boston 2017; Tremmel 2006; 2015; 2018; 2019). These institutions have been given various names. I will call them offices for future generations (OFGs); and I take them as embodiments for the future branch if they are powerful enough - that is, if OFGs are given real power by their statutes and in practice. In this last part of this chapter I will discuss the legitimacy of OFGs in the context of the four-power-model.

OFGs should be unelected bodies. While popular elections would maximize the formal independence of the organisation’s members - vis-à-vis the legislative, executive, and judicial 
branches - they would inescapably subject the election candidates to the short-termist pressures of parliamentary elections, thereby defeating the purpose for which the office was created. Given that electorates tend to be biased in favour of the present, those candidates for OFGs who promise to cater for the short-term wishes of their constituencies would be at an advantage. If the candidates for the OFG had to run campaigns and court votes, they would de facto turn into politicians. No longer would knowledge and expertise be the decisive qualities, but eloquence and smoothness.

Lacking a popular mandate, OFGs could be criticized as unaccountable, or, more drastically, as a form of 'expertocracy' (which is the same as 'epistocracy', just more negatively connoted). Expertocracy, literally meaning the rule of experts, has been discussed in political theory for a long time, arguably since Plato promoted it for Kallipolis, the utopian city in his dialogue Politeia. Here again, terminology is crucial for concept formation. Fischer (1990) highlights the dangers of 'technocracy' but, to be sure, 'technocracy' and 'expertocracy' should not be conflated. It is likely that experts in an OFG might be rather opposed to a technocratic stance. Terminologically, the model proposed here could be criticized as paving the way to a 'future-dictatorship', not a 'technocratic dictatorship', if anything at all.

But such a criticism would be unfounded. To put it into perspective, let's recall the rights of the third branch in the existing Three-Branches-Model. In many countries, constitutional courts exercise enormous power in interpreting if a specific law is compatible with the constitution. The doctrine of a living constitution allows courts to overrule parliament if the court's present interpretation of a constitution's semantics is in contradiction to passed legislation. This is of course country-specific. To this day, popular sovereignty is equated much more closely with parliamentary sovereignty in some countries than in others. But on a global level, the readiness of constitutional courts to challenge legislatures is generally increasing rather than decreasing (Rosanvallon 2011).

The debate between proponents of popular sovereignty and its most important institution, namely parliaments, on the one hand, and proponents of constitutionalism and the power of courts on the other hand, can serve as a blueprint for a debate about the democratic legitimacy of OFGs. To cut a long story short, most scholars agree that courts might be unelected bodies, but they serve democracy quite well. If this is agreed, then the charge of 'dictatorship' cannot reasonably directed against OFGs, as their competencies (if they are well-designed) come not 
even close to those of courts. 'Expertocracy', if this term is intended to be meaningful, always designates an authoritarian solution to the environmental crises. As a one-power-model in a Hobbesian sense, ${ }^{6}$ such an authoritarian construct is per se incompatible with the Four-PowerModel defended here. After all, all models of power-sharing are aimed at diffusing state power, not concentrating it. This has been formulated in the following terms: "Because man, who has power, has a propensity to misuse power when he is not prevented from doing so by boundaries, it is necessary that power is divided between many authorities, which mutually prevent each other’s misuse” (Riklin 2006, 290). Que le pouvoir arrête le pouvoir!

\section{OFGs should be proposers, not preventers}

I have argued elsewhere (Tremmel 2018) the case for a German Future Council, endowed with a right of initiative, allowing it to introduce proposals for new legislation into the parliament. OFGs, composed of independent appointees, are not at odds with the principle of democratic legitimacy if (and only if) they do not have the power to stop the law-making process of the legislative branch. The key criterion suggested here for the design of OFGs is 'proactiveness', in the sense of a right to initiate legislation. Such OFGs would use their power differently than courts, as they would not have the right to suspend laws temporarily or permanently, but only to propose them. We should think of OFGs as proposers, not preventers.

OFGs might be less able to assert themselves, compared to courts, but the power to partake in the agenda-setting of the law-making process should not be underestimated. In order to allow an OFG to place bills on the formal voting agenda, most parliaments would just have to change their rules of procedure. Bills usually have to be signed either by a party fraction or, inter-fractionally, by a certain percentage of all members of the parliament. If an OFG, in its capacity as representative for future citizens, did also get the right to initiate laws, its motions would be treated like inter-fractional motions - the proceedings of which are often shining examples of parliamentarianism.

The strengthening of the scientific and academic elements of parliamentarian debates, as suggested in my proposal, does not imply that the legislators must necessarily follow the scholarly advice of an OFG. Indeed, it would be naïve to believe that the legislature would take up and implement each and every proposal made by the Future Council. ${ }^{7}$ Rather, past experience with inter-fractional motions would suggest that parliament would pass on most of 
the Future Council's legislative initiatives to committees, where they would face a silent death by non-treatment. ${ }^{8}$ However, there is reasonable hope that at least in some cases the legislative initiatives brought forward by the Future Council might be able to garner the support of future-oriented lawmakers, as well as that of the press and public opinion.

A fourth branch of government, embodied in a Future Council, is not at odds with the principle of democratic legitimacy as long as such a new body does not have the power to stop the law-making process of the legislative branch. By limiting itself to a purely constructive role, the legitimacy of such a Future Council is ensured. The charge of an 'future-dictatorship' cannot be directed against such a Future Council as this charge only makes sense when talking about organisations that can either make or stop laws.

To be sure, the model of a Future Council as presented here transcends the dualist interpretation of science and politics spelled out in their respective binary codes of 'knowledge' and 'power'. Unlike political advisors, the independent members of a Future Council would not approach politicians as mere supplicants, hoping for a willing ear that may be lent but doesn't have to be. While on the one hand the power of decision-making fully remains with the politicians, on the other the element of long-term rationality is strengthened by parliament's obligation to at least consider the Future Council's proposals. The endemic problem of politics' resistance to advice is not entirely solved, but mitigated. In times like these, with politicians like US president Trump presenting their own 'alternative facts' by consciously disregarding - or even showing contempt for - scientific insights, there is need for a stronger coupling of politics and science. Knowledge ought to play a role in political decision-making.

\section{The prevention of an additional veto player}

The logic of proactiveness not only renders the charge of a 'future-dictatorship' (or 'ecodictatorship') invalid; it also prevents another 'veto player'. Traditionally, institutionalists have examined dichotomous classifications (unitary vs. federalist, parliamentarian vs. presidential etc.). By contrast, Tsebelis's theory of veto players (Tsebelis 2002) asks how many actors must consent to a decision or are able to veto it. Multi-level parliamentarianism already features a high number of veto players, such as the second legislative chamber, the constitutional court, the president (if he or she has to formally sign laws in parliamentary systems), and the people itself, insofar as it makes itself heard through referenda. 
There is a risk that creating a fully operational OFG will result in the addition of a new veto player, thereby increasing the chances of gridlock in the political system. In contrast to some theories that advocate slowing democracy down (Clark and Teachout 2012, Ekeli 2009), I see political gridlock as a drawback in times when problems such as climate change demand urgent action. Not slowing down the political system is a strong additional argument for giving OFGs the right to initiate legislation, but not the right to prevent it.

The right to delay law-making (for a limited period of time, not indefinitely) seems to lie somewhat in between the input and the output side of the political process. But in fact, postponement rights are not initial or constructive actions; they are part of a reactive capacity. They can be a sharp sword too, as Shlomo Shoham, the one and only Knesset Commissioner for Future Generations in Israel, explains: "The right to be given enough time to prepare an opinion is an implied authority to create a delay in the legislative process. Such a delay may be crucial for the parliamentary work when it comes to bills discussed in the framework of the state's budget. In that case, the time factor is vital since the implication of not voting on the state's budget for the next year (...) is that parliament must dissolve itself and go to elections” (Shoham/Lamay 2006, p. 248). While this might be a peculiarity of the political system in Israel, the US-American experience with filibustering highlights that delaying resistance is often difficult to overcome at all.

Independent bodies have been a fundamental part of democratic architecture since classical Athens - just think of scrutineers, auditors, supervisors and later constitutional courts and public ombudsman. The role of such bodies is supportive for democracy as they equip it against the anxieties of the majoritarian principle. OFGs are democratically legitimized as long as they are granted their status by law - and as long as this status can be revoked by law as well (Rosanvallon 2011). Unelected representatives of future citizens, appointed by elected politicians but not for their pleasure (Pettit 2012, 306), are a necessary and legitimate instrument against political presentism.

\section{Conclusion}

OFGs are more than just a vision or illusion. The future-orientated part of the political class takes a genuine interest in amending the rules of the game so as to engage the selfcommitment of the entire political class. This nourishes the hope that a special version of 
OFGs, future councils characterized by the right to initiate legislation, will eventually come into existence. An increasing number of experiments with such bodies, and the lessons learnt, alter the political landscapes in more and more countries in a both spirited and innovative way. The problem of political presentism cannot be solved, only alleviated. But limiting the size of this problem would be no small achievement. In fact, it is of paramount importance for the future of humankind. 


\section{Notes}

${ }^{1}$ The 'Six Ages of the World' (Latin: sex aetates mundi) doctrine was a Christian periodisation put forward by Church Father Augustine of Hippo (354-430), which endured well into the Middle Ages. It was repudiated during the Enlightenment. The pioneer geological works by Georges-Louis Leclerc, Comte de Buffon (1707-1788) and Charles Lyell (1797-1875) paved the way towards the modern worldview which rests upon scientific insights rather than on assertions from Holy Scriptures.

${ }^{2}$ Others have suggested similar concepts much earlier, such as 'anthropolithic era' (Haeckel 1870), 'anthropozoic era' (Stoppani 1873), and 'Noosphere' (Teilhard de Chardin 1923).

${ }^{3}$ The potential of the following new mission statement would be particularly relevant for school curricula (Crutzen/Schwägerl 2011). The term 'Anthropocene' might help students to grasp the idea of the enormous impact of humankind on nature. The pupil who carelessly used to dispose of his candy wrapper in nature, thinking that it would decompose quickly there, might be inspired to change his behaviour by the concept of an Anthropocene.

${ }^{4}$ Haber (2015, p. 29, own translation) describes urbanisation as the constitutive feature of the Anthropocene: "It is due to this development that from an ecological point of view, one can base the Anthropocene on one criterion alone - to wit, on the greatest possible centralisation of the a central system 'nature' - with its transformation into culture - towards its human user who is centred around the city."

${ }^{5}$ To which it must be added that the future is not a moral object (moral patient) in itself, and rather what is of concern here are human beings living in the future - hence for a diachronic, temporal ethics, the notion of 'generational ethics' is more appropriate than the term 'future ethics'.

${ }^{6}$ For Hobbes, men only overcome the state of nature when they agree upon a social contract amongst themselves, which subordinates them to the rule and authority of an abstract body. In the Leviathan (1651), Hobbes writes: "The only way to erect such a common power, as may be able to defend them from the invasion of foreigners, and the injuries of one another, and thereby to secure them in such sort as that by their own industry and by the fruits of the Earth they may nourish themselves and live contentedly, is to confer all their power and strength upon one man, or upon one assembly of men, that may reduce all their wills, by plurality of voices, unto one will: which is as much as to say, to appoint one man, or assembly of men, to bear their person; and every one to own and acknowledge himself to be author of whatsoever he that so beareth their person shall act, or cause to be acted, in those things which concern the common peace and safety; and therein to submit their wills, every one to his will, and their judgements to his judgement” (2000, 105-106).

${ }^{7}$ When I write Future Council, I am referring to the here described specific OFG (with the right to initiate laws), using capital letters to distinguish it from the more generic usage of the term future council.

${ }^{8}$ For a more comprehensive account, including some Figures, of the treatment of interfractional motions in the German Parliament, see Tremmel 2018. 


\section{References}

Barry, J. (1999): Greening political theory. London: Sage.

Boston, J. (2017): Governing for the future. Designing democratic institutions for a better tomorrow. Bingley: Emerald.

Chen, A. (2014): Rocks Made of Plastic Found on Hawaiian Beach. Science, 4 June 2014. http://www.sciencemag.org/news/2014/06/rocks-made-plastic-found-hawaiian-beach. Accessed 16 April 2018

Clarke, S. / Teachout, W. (2012): Slow Democracy. Rediscovering community, bringing decision making back home. White River Junction: Chelsea Green Publishing.

Crutzen, P. / Schwägerl, C. (2011): Living in the Anthropocene: Toward a New Global Ethos. http://e360.yale.edu/feature/living_in_the_anthropocene_toward_a_new_global_ethos/2363/. Accessed 16 April 2018

Eckersley R. (2004): The green state: Rethinking democracy and sovereignty. Cambridge, Mass./London: MIT Press.

Ekeli K. (2009): Constitutional experiments: representing future generations through submajority rules. Journal for Political Philosophy, 17 (4), 440-461.

Freud, S. (1920): A General Introduction to Psychoanalysis. New York, NY: Horace Liveright.

González-Ricoy, I. / Gosseries, A. (eds.) (2016): Institutions for Future Generations. Oxford: Oxford University Press.

Görg C. (2016) “Zwischen Tagesgeschäft und Erdgeschichte. Die unterschiedlichen Zeitskalen in der Debatte um das Anthropozän” GAIA 25/1 (2016): 9-13.

Haber W. (2016) “Anthropozän - Folgen für das Verhältnis von Humanität und Ökologie”. In: Haber, W. / Held, M. /Vogt, M. (eds.): Die Welt im Anthropozän. Erkundungen im Spannungsfeld zwischen Ökologie und Humanität. München: oekom. 19-37. 
Hammond, M. / Smith, G. (2017): Sustainable Prosperity and Democracy - A Research Agenda. CUSP Working Paper no.8. Guildford: University of Surrey.

Hobbes, T. (2000): Leviathan.

http://socserv.mcmaster.ca/econ/ugcm/3ll3/hobbes/Leviathan.pdf. Accessed 16 April 2018.

Jänicke, M. (1996): Democracy as a condition for environmental policy success. In: Lafferty, W. M. / Meadowcroft, J. (eds.): Democracy and the Environment. Cheltenham: Edward Elgar, 71-85.

Leinfelder, R. (2017): “Die Erde wie eine Stiftung behandeln”. Stuttgarter Zeitung. No. 37 (14 Feb 2017): 16.

Locke, J. (1823): Two Treatises of Government.

http://socserv.mcmaster.ca/econ/ugcm/3ll3/locke/government.pdf. Accessed 16 April 2018.

Mill, J. S. (1977): The Collected Works of John Stuart Mill. Vol. 18. Essays on Politics and Society. Ed. by J. Robson. Toronto: University of Toronto Press; London: Routledge \& Kegan Paul.

Montesquieu, C. (2001): The Spirit of Laws. Translated by T. Nugent. Kitchener: Batoche Books. (Original edition: De l'esprit des lois, 1748.)

Jonas, H. (1984): The Imperative of Responsibility: In Search of Ethics for the Technological Age. Chicago, IL: University of Chicago Press.

Ophuls, W. (1977): Ecology and the Politics of Scarcity. San Francisco: W.H. Freeman.

Randers, J. (2012): 2052 - A Global Forecast for the Next Forty Years. White River Junction: Chelsea Green Publishing.

Riklin. A. (2006): Machtteilung. Geschichte der Mischverfassung. Darmstadt: Wiss. Buchges. 
Rosanvallon, P. (2011): Democratic Legitimacy: Impartiality, Reflexivity, Proximity.

Princeton: Princeton University Press.

Pettit, P. (2012): On the People's Terms: A Republican Theory and Model of Democracy. Cambridge: Cambridge University Press.

Smil, V. (2002): The Earth’s Biosphere: Evolution, Dynamics, and Change. Cambridge, Mass.: MIT Press.

Shearman, D. / Smith, J. W. (2007): The Climate Change Challenge and the Failure of Democracy. Westport: Praeger Publishers.

Shoham, S. / Lamay, N. (2006): Commission for future generations in the Knesset: lessons learnt. In: Tremmel, Jörg C. (ed.): Handbook of Intergenerational Justice. Cheltenham: Edward Elgar, 244-262.

Spaemann, R. (1989): Glück und Wohlwollen. Stuttgart: Klett-Cotta.

Steffen, W. et al. 2015. The trajectory of the Anthropocene: The Great Acceleration. The Anthropocene Review (2/1): 81-98. http://anr.sagepub.com/content/2/1/81

Stein, T. (1998): Does the Constitutional and Democratic System Work? The Ecological Crisis as a Challenge to the Political Order of constitutional Democracy. In: Constellations. Vol. 4 (3), 420-449.

Tocqueville, Alexis de (1835/1840): Democracy in America. https://www.gutenberg.org/files/815/815-h/815-h.htm.

Thompson, Dennis F. (2010): Representing future generations: political 'presentism' and democratic trusteeship. In: Critical Review of International Social and Political Philosophy. 13 (1), $17-37$.

Tremmel, J. (2019): Offices for Future Generations - Justification, Typology and Some Key Design Criteria. In: Szabó, Marcel / Cordonier Segger, Marie-Claire (eds.): Intergenerational 
Justice in Sustainable Development Treaty Implementation. Cambridge University Press. Forthcoming.

Tremmel, J. (2018): Zukunftsräte zur Vertretung der Interessen kommender Generationen. Ein praxisorientierter Vorschlag für Deutschland. In: Mannewitz, Tom (ed.): Die Demokratie und ihre Defekte. Heidelberg: Springer VS. 107-142.

Tremmel, J. (2015): Parliaments and future generations - the Four-Powers-Model. In: Birnbacher, Dieter / Thorseth, May (eds.): The Politics of Sustainability. Philosophical Perspectives. London: Routledge/Earthscan. 212-233.

Tremmel, J. (2009): A Theory of Intergenerational Justice. London: Earthscan.

Tremmel, J. (2006): Establishment of intergenerational justice in national constitutions. In: Tremmel, J. (ed.): Handbook of Intergenerational Justice. Cheltenham: Edward Elgar Publishing. 187-214.

Vince, G. (2011): An Epoch Debate. Science, 7 Oct 2011, 32-27.

WBGU (Wissenschaftlicher Beirat der Bundesregierung Globale Umweltveränderungen) (2011): World in Transition - A Social Contract for Sustainability. http://www.wbgu.de/en/flagship-reports/. Accessed 16 April 2018

Waters, C.N. / Zalasiewicz, J. / Williams, M. / Ellis, M.A. / Snelling, A.M. (eds) (2016): A Stratigraphical Basis for the Anthropocene. Geological Society. Special Publication 395. http://www.geolsoc.org.uk/sp395. Accessed 16 April 2018

Weber, M. (1972): Wirtschaft und Gesellschaft: Grundriss der verstehenden Soziologie. ed. by J. Winckelmann. Tübingen: Mohr-Verlag. (first published 1921/1922). 